DOI: 10.31866/2617-7951.4.2.2021.246841

ІНТЕЛЕКТУАЛЬНІ СИСТЕМИ

ТА ТЕХНОЛОГІї

У ФОРМУВАННІ ПРОСТОРУ KOBOРКІНГУ

Інна Бірілло, https://orcid.org/0000-0002-2690-9621 кандидат технічних наук, доцент, Київський національний університет культури і мистецтв, Київ, Україна innabirillo@knukim.edu.ua

Єлизавета Богачек, https://orcid.org/0000-0002-2145-0495 магістр дизайну, Київський національний університет культури і мистецтв,

Київ, Україна bogachek16@gmail.com

\section{INTELLECTUAL SYSTEMS \\ AND TECHNOLOGIES \\ IN THE COWORKING SPACE \\ ORGANIZATION}

Inna Birillo,

https://orcid.org/0000-0002-2690-9621

$\mathrm{PhD}$ in Technical Sciences,

Associate Professor,

Kyiv National University

of Culture and Arts,

Kyiv, Ukraine

innabirillo@knukim.edu.ua

\section{Yelyzaveta Bohachek,}

https://orcid.org/0000-0002-2145-0495

Master of Design,

Kyiv National University

of Culture and Arts,

Kyiv, Ukraine

bogachek16@gmail.com

\section{Анотація}

Мета статті полягає у виявленні особливостей формування коворкінгів, відповідно до можливостей використання інтелектуальних систем та технологій в організації робочого простору основних та другорядних зон просторово-функціональної організації. Методологія дослідження побудована на використанні теоретичних методів: наукометричний метод, аналіз вітчизняного та закордонного досвіду проєктування та будівництва досліджуваного об'єкту, аналіз вітчизняних та закордонних стандартів та нормативних документів з теми дослідження, і емпіричних методів: метод структурного аналізу, метод експериментального

\begin{abstract}
The purpose of the article is to identify the features of the coworking space design, in accordance with the possibilities of using intelligent systems and technologies in the organization of the main and secondary working space zones of the spatial-functional organization. The research methodology is based on the use of theoretical methods: scientometric method, analysis of domestic and foreign experience in the design and construction of the object, analysis of domestic and foreign standards and regulations on the research topic, and empirical methods: structural analysis method, experimental design method, structural method -functional modeling. The scientific novelty of
\end{abstract}


проєктування, метод структурно-функціонального моделювання. Наукова новизна одержаних результатів полягає в узагальненні й систематизації основних прийомів та особливостей формування гнучкого простору коворкінгів. Вперше виявлено та систематизовано застосування інтелектуальних систем та інноваційних технологій до функціональних зон основного і другорядного значення. Висновки. У результаті проведеного дослідження було виявлено основні закономірності формування коворкінг-просторів для створення цілісного гармонійного предметно-технічного простору середовища життєдіяльності людини. Виділено 3 групи користувачів коворкінгу (власники, працівники, резиденти), відповідно до яких обґрунтовано вимоги до офісного простору. Функціональне зонування коворкінгу дозволило конкретизувати можливості використання інтелектуальних систем та інноваційних технологій у кожній окремій зоні та розробити рекомендації щодо їх використання. У результаті дослідження було систематизовано ефективність використання офісних меблів та аксесуарів для комбінування форматів роботи протягом дня. Було обґрунтовано доцільність застосування інтелектуальних систем для зміни робочого настрою на атмосферу відпочинку і спокою, а також використання обладнання для фізичних навантажень у спортивних кімнатах простору коворкінгу. Установка таких інтелектуальних систем та інноваційних технологій стає яскравим індикатором прояву піклування про фізичне й ментальне здоров'я резидентів, що відповідає останнім тенденціям із застосуванням інноваційних технологій та розумних систем.

\section{Ключові слова:}

дизайн інтер'єру, коворкінг-простори, інноваційні технології, наноматеріали, інтелектуальні системи, гнучкі офіси, креативний простір, відкритий простір, офісне приміщення. the obtained results lies in the generalization and systematization of the basic techniques and features of the flexible coworking space design. For the first time, the application of intelligent systems and innovative technologies to functional areas of primary and secondary importance has been identified and systematized.

Conclusions. As a result of the conducted research the basic regularities of formation of coworking spaces for creation of integral harmonious subject-technical space of the environment of human life were revealed. There are 3 groups of coworking users (owners, employees, residents), according to which the requirements for office space are justified. Functional zoning of coworking allowed to specify the possibilities of using intelligent systems and innovative technologies in each zone and to develop recommendations for their use. As a result of the study, the effectiveness of the use of office furniture and accessories to combine work formats during the day was systematized. The expediency of using intelligent systems to change the working mood to an atmosphere of rest and relaxation, as well as the use of equipment for physical activity in the sports rooms of the coworking space was substantiated. The installation of such intelligent systems and innovative technologies is becoming a clear indicator of the concern for the physical and mental health of residents, which is in line with the latest trends in the use of innovative technologies and intelligent systems.

\section{Keywords:}

interior design, coworking spaces, innovative technologies, nanomaterials, intellectual systems, flexible offices, creative space, open space, office space. 
Вступ 1 Модернізація сучасного дизайну залежать від інноваційних технологій, націлених на створення адаптивного сучасного дизайну, який має властивість пристосовуватись до змін умов експлуатації і тим самим забезпечує актуальність інтер'єру на роки. Серед інтер'єрів, які найбільш потребують адаптивності явно вирізняються громадські простори, які мають одночасно виконувати різні функції, а їх користувачами є багато різних людей одночасно з власними завданнями і вподобаннями. Поміж різних типів громадських просторів набувають актуальності коворкінги.

Коворкінг-центри відрізняються гнучкістю і мобільністю це просторі зали, які легко переобладнуються із сукупності робочих місць в аудиторію для обговорення та виступів спікерів, проведення майстер-класів. Вони складаються не тільки з робочого простору, а й зони розваг, обладнані офісними меблями, оргтехнікою, інтернетом тощо. Коворкінг спрямований на стимулювання найпершої стадії інноваційного процесу формування ідей (Олешко \& Петровська, 2018). Зі зростанням кількості інновацій у світі зростає і кількість тих, хто продукує креативні й оригінальні ідеї й системи. А це означає, що і попит на гнучкі офіси з можливістю оренди робочих місць зростає, зі зростанням попиту, що у свою чергу визначає ріст обсягів пропозиції у сфері коворкінг-центрів. Для забезпечення конкурентоспроможності, бізнесу у сфері оренди місць у креативному просторі варто приділяти більше уваги дизайну внутрішнього середовища і звертати якомога більше уваги на використання інноваційних технології в інтер'єрі майбутнього коворкінгу.

\section{Мета дослідження}

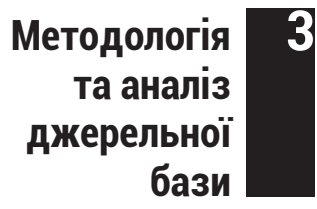

Мета статті - у виявленні особливостей формування коворкінгів у відповідності до можливостей використання інноваційних технологій в організації робочого простору основних та другорядних зон просторово-функціональної організації.

Для розв'язання поставлених завдань використовувався комплекс взаємопов'язаних методів дослідження. Серед них теоретичні: наукометричний метод, аналіз вітчизняного та закордонного досвіду проєктування та будівництва досліджуваного об'єкту, аналіз вітчизняних та закордонних стандартів та нормативних документів з теми дослідження; емпіричні: спостереження, анкетування, метод структурного аналізу, метод експериментального проєктування, метод структурно-функціонального моделювання тощо.

Аналіз останніх досліджень та публікацій засвідчив, що українські дослідники звернули увагу лише на деякі аспекти дизайнерського оформлення коворкінг-простору. Наприклад, вимоги до формування дизайну інтер'єру, ергономічність і доступність 
коворкінг-центрів на базі вищих навчальних закладів аналізують Ю. Радченко та О. Шмельова (2018); провідні тенденції проєктування коворкінг-просторів розглянуто в науковій статті О. Шмельовою, О. Сафроновою, Т. Булгаковою та М. Синицькою (Шмельова та ін., 2019), особливості використання в інтер'єрах коворкінг-центрів елементів фітодизайну досліджено О. Олешко та Ю. Петровською (2018) та ін. Проте особливості застосування інноваційних технологій у коворкінг-центрі залишаються невисвітленими, а тому потребують глибокого дослідження.

Результати
дослідження

Офіс - складна система, де будь-який елемент впливає на ефективність роботи компанії. Завдання проєктувальника знайти в кожному випадку оптимальне рішення, не перевищуючи певного бюджету. На макрорівні це вирішується за допомогою аналізу вимог замовника, його організаційної структури, функціональних зв'язків і створенням оптимального планувального рішення, на мікрорівні - проєктуванням ергономічних робочих місць, якісних матеріалів оздоблення і зручного обладнання, створенням комфортного середовища (Олійник та ін., 2011).

Гнучкий офіс - це модель організації роботи людей, найчастіше фрілансерів, зі спільними цінностями та інтересами, проте з різним типом зайнятості у єдиному робочому просторі. Результатом взаємодії у такому просторі є створення спільноти однодумців. Такий офіс $є$ спільним для людей з різними вподобаннями, життєвими цінностями і професійними навичками, а тому і сам простір має бути багатофункціональним. У дизайні інтер'єру багатофункціональність простору досягається завдяки коректній просторово-функціональній організації, яка враховує поділ приміщення на основні та другорядні зони (рис.1). Спершу перелічимо зони, наявність яких обов'язкова в будь-якому коворкінгу, незалежно від розмірів і концепції:

- Інтегральна зона;

- Зона харчування;

- Громадська зона;

- Робочий простір.

Існує також набір другорядних зон, які можуть бути відсутніми в коворкінгу, проте їхня наявність неодмінно покращить рівень комфорту, а разом з тим сприятиме зниженню рівня стресу й підтримці здоров'я працівників:

- рекреаційна зона, інтерпретація якої може бути дуже широкою. Кожен офіс обирає такі типи відпочинку, які притаманні і цікаві його працівникам; яскраві приклади, які нерідко зустрічаються в сучасних просторах - кімнати для йоги, спортзали, зали тиші й окремі острови релаксу у загальній зоні спільного користування; 
- технологічна зона, що також може інтерпретуватись досить широко і залежати від уподобань власників і користувачів. Наприклад, це можуть бути інтегровані зони по всьому периметру простору для перевірки психологічного і фізичного стану, а також VR-кімнати для релаксу;

- VIP-зона як унікальна зона зі специфічним дизайном у якості унікальної родзинки коворкінгу.

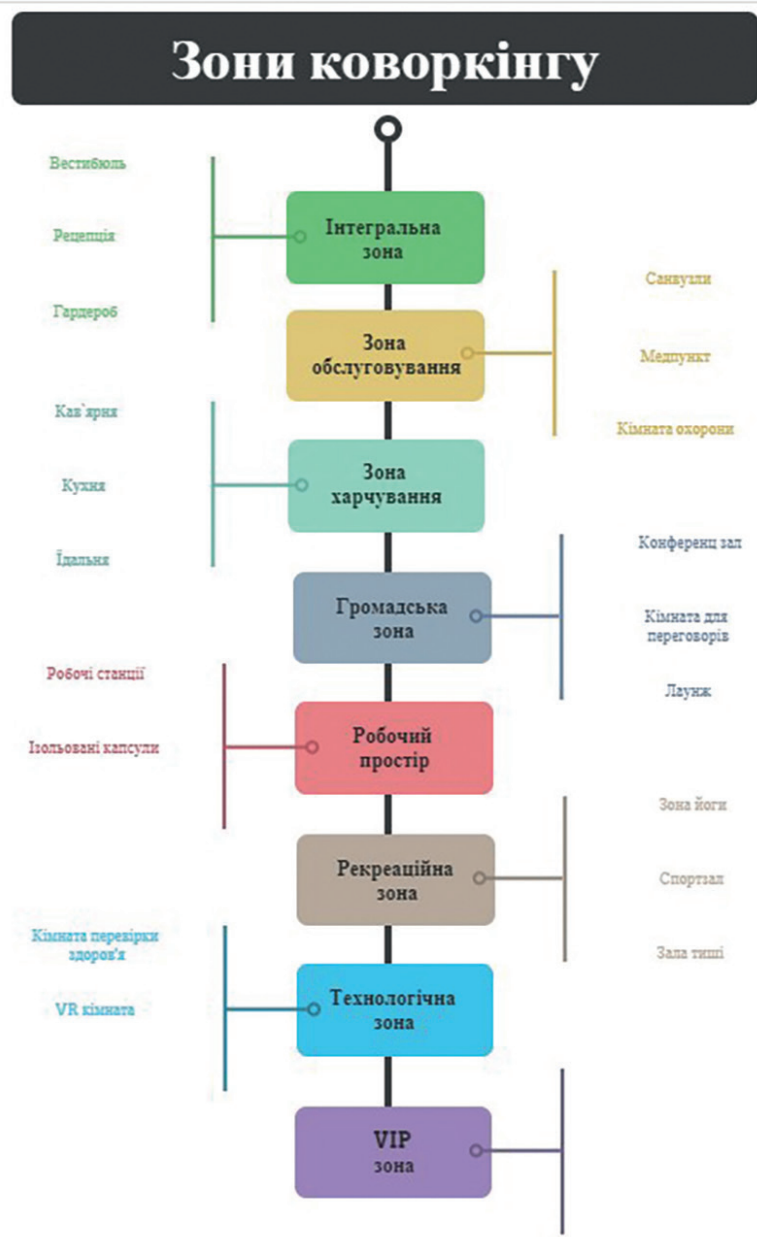

Рис. 1. Ієрархія зон коворкінгу.

Fig. 1. Hierarchy of coworking zones.

Наступний крок - аналіз вимог і потреб замовника та всіх інших майбутніх сторін-учасників процесу. Усіх зацікавлених можна поділити на три групи:

1 група - власники з їхніми бізнес-інтересами

2 група - працівники з потребами комфортних умов праці,

3 група - резиденти, користувачі коворкінгу, які орендують певну частину простору. Основна ціль резидентів від такої угоди - отримати максимум користі від витрачених грошей. 
Деміург: ідеї, технології, перспективи дизайну 2021 Том 4 № 2 Demiurge: ideas, technologies, perspectives of design 2021 Vol. 4 No 2

Для формування ергономічного робочого простору необхідно зрозуміти інтереси кожної з цих груп на предметний дизайн і використання обладнання коворкінгу.

Власники коворкінгу

Компанія Cushman\&Wakefield провели дослідження (Di Risio, 2020) й визначили частку прибутку в сегменті гнучких офісів, до якого й належать коворкінги, для кожної послуги, яку надає простір (рис. 1).

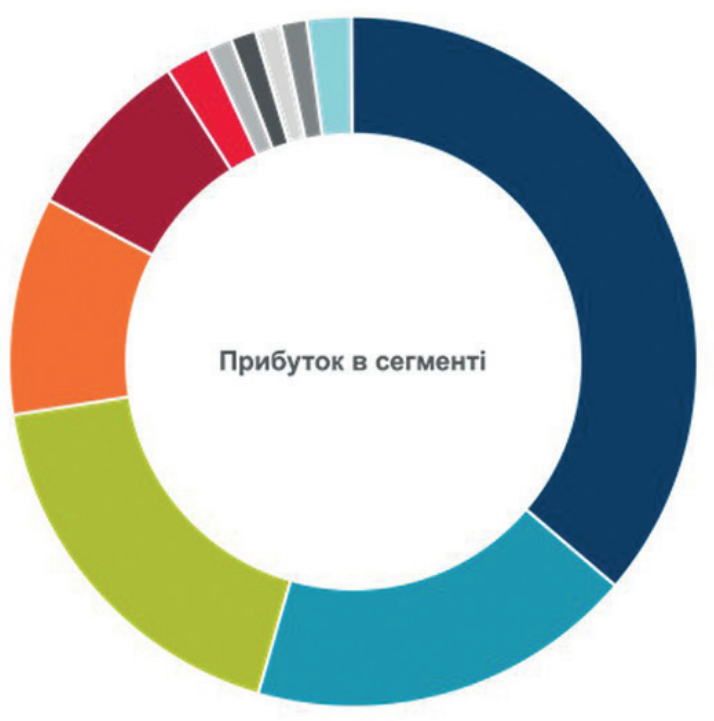

Оренда робочого місця

Комбіноване планування

Оренда окремого офісу

Оренда кімнат для переговорів

Оренда приміщень для заходів та семінарів

Послуги для віртуального офісу

Продаж квитків на внутрішні заходи

Спонсорство
Рис. 2. Статті прибутку в сегменті гнучких офісів.

Fig. 2. Profit items in the segment of flexible offices.

До ТОП-5 послуг за об'ємом прибутку відноситься оренда робочого місця, оренда окремого офісу, комбіноване планування, оренда кімнат для переговорів, оренда приміщень для заходів та семінарів. Це визначає пріоритетність, якою керуватиметься власник бізнесу, приймаючи рішення щодо наявності й відносної площі різних зон у коворкінгу. Таким чином, найбільш важливим залишається відкритий простір з окремими робочими станціями з можливістю реорганізації простору в декілька відокремлених офісів. Проте, варто приділити увагу й ізольованим кімнатам різної площі, які зможуть трансформуватись із кількох кімнат для переговорів в одне загальне приміщення для заходів і семінарів. 
Крім визначення, яким функціям віддати перевагу при проєктуванні коворкінгу, власнику ще й важливо розрахувати бюджет, який буде витрачено на створення простору, а в подальшому на підтримку його стану. Для цього добре підійдуть матеріали з наноелементами, які забезпечують стійкість до численних зовнішніх подразників:

- тканини для оббивки м'яких меблів: використана при створені тканини, технологія Nano-Tex відштовхує будь-які рідини, що означає стійкість до будь-яких плям без потреби використання хімчистки;

- лінія шпалер з нанокерамічним покриттям під назвою Ccflex: наношпалери пропускають повітря, при цьому стійкі до впливу води і вогню, а також до механічних і хімічних впливів.

Працівники коворкінгу

До цієї групи належать адміністратори, основною задачею яких є забезпечити управління бронюванням робочих місць/ офісів. Сучасний формат передбачає ефективне використання інноваційних інструментів управління загального простору, автоматизацію оpen-space з можливістю планувати завантаженість закладу, контролювати час перебування відвідувачів, керувати доступом відвідувачів до певних зон або сервісів тощо. Можна було б вказати, які моделі планшетів, моніторів чи сенсорних стійок самообслуговування допоможуть якнайкраще досягти цієї мети, але жоден із перелічених елементів не наблизить цю групу користувачів до їхньої мети без правильно підібраного програмного забезпечення. Сучасними варіантами програмного забезпечення, створеного для спрощення процесу управління коворкінгом є:

- SERVIO POS Coworking - основний програмний продукт для автоматизації коворкінгів, антикафе і хабів, де ведуться всі розрахункові операції з клієнтами, забезпечується бронювання робочих місць і конференц-залів, є можливість контролю наявності вільних і зайнятих місць у коворкінгу.

- AndCards - мобільне програмне забезпечення з розширеним набором функцій від бронювання кімнат і столів до ведення бізнес-документації, організації заходів і налаштування взаємодії із партнерами.

Резиденти коворкінгу - це споживачі послуги, яку надає даний бізнес. Вони визначають його успішність, а це означає, що їхній досвід є визначальним чинником, на який потрібно спиратись при організації простору. 3 одного боку, орендар коворкінгу обирає даний вид зайнятості, оскільки в домашніх умовах працює неефективно, але з іншого боку - він хотів би відчувати себе як вдома. Таким чином, баланс між робочою й домашньою атмосферами є одним із головних завдань при плануванні коворкінгу. Від інтер'єру коворкінгу безпосередньо залежить 
Деміург: ідеї, технології, перспективи дизайну 2021 Том 4 № 2 Demiurge: ideas, technologies, perspectives of design 2021 Vol. 4 No 2

те, як буде відчувати себе користувач. Головними аспектами, на які варто звернути увагу, є максимальний комфорт під час роботи за комп'ютером, гарне місце розташування, гнучкі графіки відвідування, наявність кімнат для переговорів, нарад і навіть наявність душових кабін.

Систематизувавши отримані дані, можна вивести матрицю залежності інновацій від пропозицій застосування інноваційних технологій у кожній функціональній зоні для покращення можливостей користування нею.

Інноваційні технології, доцільні для використання у відкритому робочому просторі для забезпечення продуктивної та творчої атмосфери, представлені в таблиці 1.

Таблиця 1. Розумні системи для відкритого робочого простору

Table 1. Smart systems for open workspace

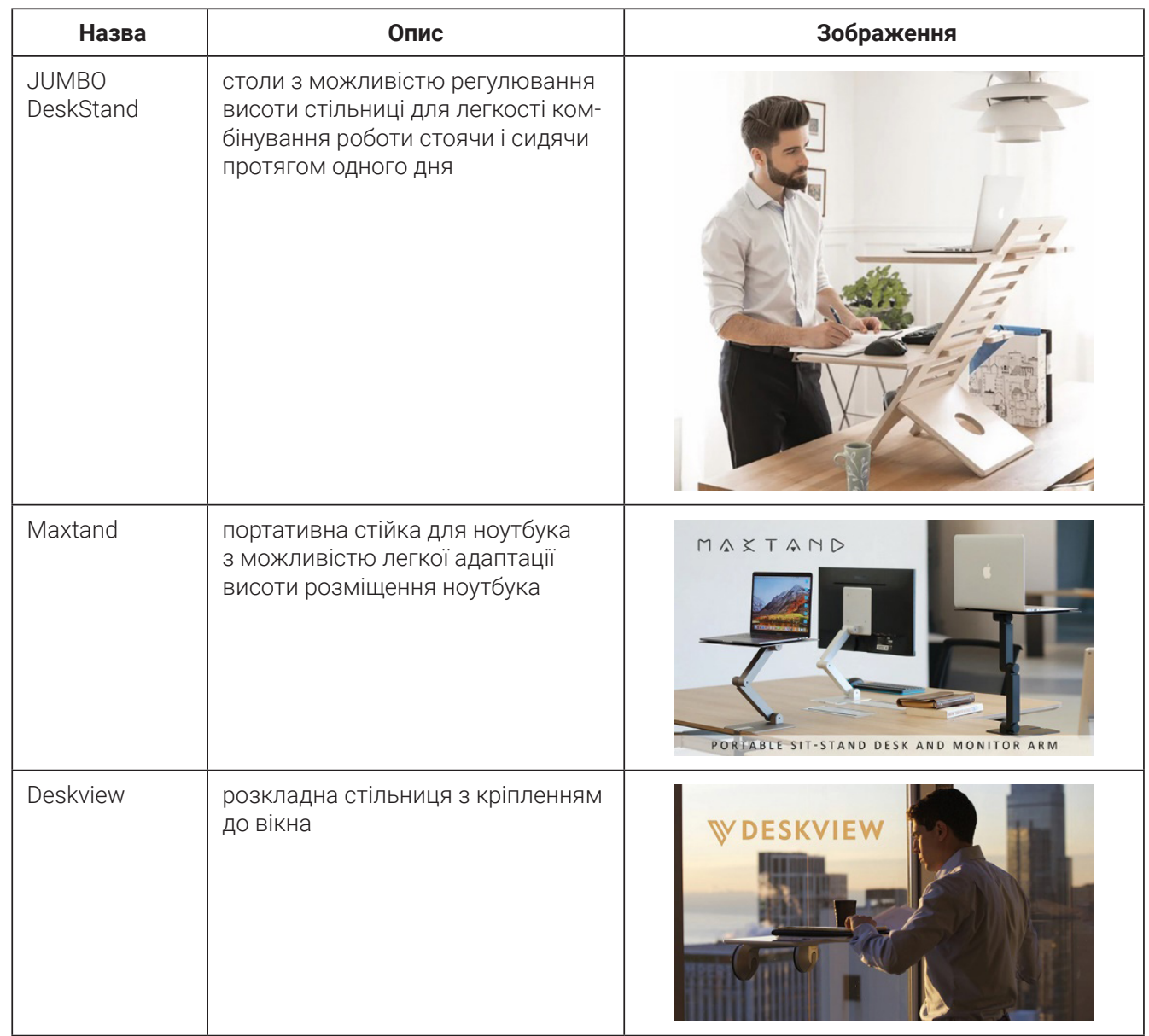


Дизайн середовища

Design of the environment

Продовження табл. 1

\begin{tabular}{|c|c|}
\hline Myoto Chair & $\begin{array}{l}\text { стілець, у якому використовують- } \\
\text { ся наночастинки, що підвищують } \\
\text { його пластичність. У місці спинки } \\
\text { цей стілець підлаштовується під } \\
\text { форму тіла сидячого і у такий } \\
\text { спосіб дозволяє розслабити } \\
\text { спину і значно підвищити рівень } \\
\text { комфорту }\end{array}$ \\
\hline ХіҮао крісло & $\begin{array}{l}\text { крісло, яке поєднує в собі одно- } \\
\text { часно чотири функціонали: офісне } \\
\text { крісло, стіл, диван і навіть крісло } \\
\text { для масажу }\end{array}$ \\
\hline Darma & $\begin{array}{l}\text { розумна подушка - це перша } \\
\text { в світі розумна подушка, яка } \\
\text { контролює вашу поставу, звички } \\
\text { сидіння, рівень стресу та слідкує } \\
\text { за осанкою }\end{array}$ \\
\hline Eilik & $\begin{array}{l}\text { інтерактивний настільний ро- } \\
\text { бот-компаньйон з емоціями та } \\
\text { персонажем, його мета - зробити } \\
\text { ваш день яскравішим і змусити } \\
\text { посміхатись }\end{array}$ \\
\hline
\end{tabular}


Деміург: ідеї, технології, перспективи дизайну 2021 Том 4 № 2

Demiurge: ideas, technologies, perspectives of design 2021 Vol. 4 No 2

Продовження табл. 1

\begin{tabular}{|l|l|l|}
\hline FootROK & $\begin{array}{l}\text { компактний портативний і ефек- } \\
\text { тивний тренажер для ніг при } \\
\text { сидінні, який покращує кровообіг, } \\
\text { зменшує біль і скутість суглобів }\end{array}$ \\
\hline $\begin{array}{l}\text { Smart Herb } \\
\text { Garden }\end{array}$ & $\begin{array}{l}\text { настільні автономні міні-сади, які } \\
\text { є натуральною прикрасою робо- } \\
\text { чого столу, виготовлені компанією } \\
\text { СІік \& Gгош }\end{array}$ \\
\hline SproutsIO & $\begin{array}{l}\text { автоматизована система вирощу- } \\
\text { вання рослин у приміщенні }\end{array}$ \\
\hline
\end{tabular}

Під час будь-яких переговорів важливою є конфіденційність обговорюваної інформації та комфорт резидентів. Використання певних інноваційних технологій сприяє виконанню вищевказаних вимог для відокремлених кімнат для переговорів:

- HoloPresence ${ }^{\text {тм }}$ (Рис. 3) - технологія, розроблена ARHT Media, для зйомки та відображення одного або декількох доповідачів у високій якості та з малою затримкою, щоб вони могли з'явитися у прямому ефірі в іншій локації. Натуральний вигляд людини забепечує реалістична тривимірна голограма. завдяки цьому доповідач може взаємодіяти з аудиторією, людьми та навіть іншими голограмами. Такий метод краще залучає учасників до взаємодії дистанційно, ніж простий перегляд екрана комп'ютера. 


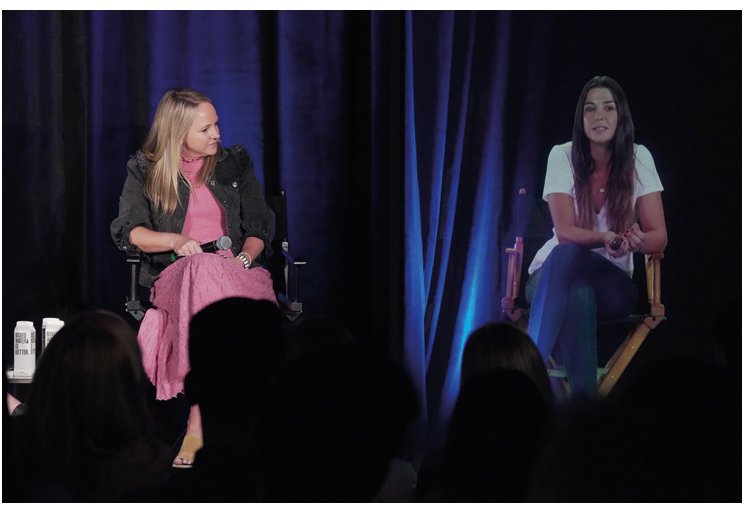

Рис. 3. HoloPresence - технологія голограми.

Fig. 3. HoloPresence - hologram technology

До побутових вимог, які стосуються кухні, варто додати інноваційні рішення, які лише покращують самопочуття працівників під час обідньої перерви:

- OCTOPUS (рис. 4) - розширена світлодіодна система з вбудованою камерою, автоматичним затемненням і віддаленим моніторингом через Wi-Fi.

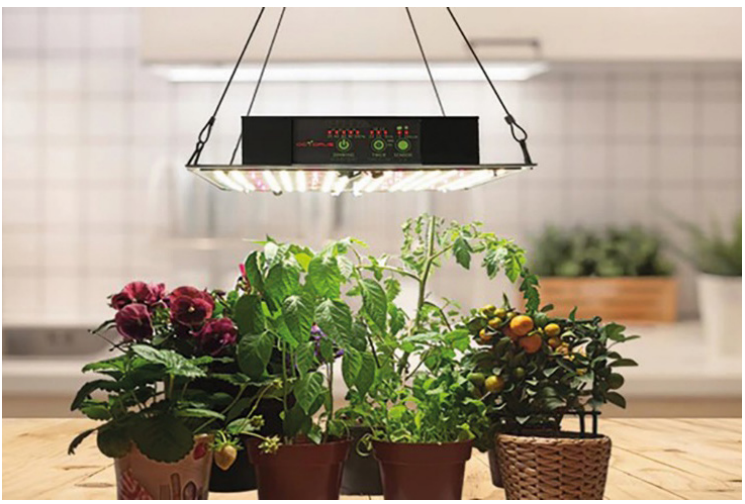

Рис. 4.Світлодіодна система OCTOPUS

Fig. 4. LED system OCTOPUS.

У місці, призначеному для відпочинку працівників важливо забезпечити можливість абстрагуватись від усіх зовнішніх впливів. Для цього варто використати системи, описані в таблиці 2.

Використання технологій, зазначених у таблиці 3, полегшить процес розвантаження м'язів протягом робочого дня працівника.

Навіть у кімнаті, вільній від електронних приладів є місце для сучасних інноваційних технологій, які сприяють зменшенню впливів усіх навколишніх подразників. Наприклад, килим від німецького виробника Dura Tufting $\mathrm{GmbH}$, який не тільки не збирає пил, але й очищає повітря від запахів і шкідливих випарів.

Головним трендом сучасного інтер'єру є підвищення вимог до зниження споживання різних ресурсів і особливо енергетичних для створення і експлуатації інтер'єрів різного призначення 
Деміург: ідеї, технології, перспективи дизайну 2021 Том 4 № 2 Demiurge: ideas, technologies, perspectives of design 2021 Vol. 4 No 2

Таблиця 2. Інноваційні технології для кімнат відпочинку в коворкінгу

Table 2. Innovative technologies for coworking lounges

\begin{tabular}{|c|c|c|}
\hline Назва & Опис & Зображення \\
\hline Flic Twist & $\begin{array}{l}\text { бездротовий розумний світильник, } \\
\text { інтегрований з музичною колонкою, } \\
\text { контрольованою за допомогою голосу } \\
\text { й мобільних додатків }\end{array}$ & \\
\hline Boxe & $\begin{array}{l}\text { портативний вишуканий проєктор } \\
\text { із потужністю великого екрану }\end{array}$ & \\
\hline Glyph & $\begin{array}{l}\text { персональний мобільний кінотеатр } \\
\text { із вбудованою аудіосистемою премі- } \\
\text { ум-класу }\end{array}$ & \\
\hline
\end{tabular}

Це зумовлено поширенням у світі стандартів енергозбереження, вироблених у найрозвиненіших країнах світу. Сьогодні існує багато розробок конструкцій, обладнання й оздоблювальних матеріалів, які мають властивість накопичення і навіть виробництва електричної та теплової енергії. 
Дизайн середовища

Design of the environment

Таблиця 3. Інноваційні системи для кімнат спорту в коворкінгах

Table 3. Innovative systems for sports rooms in coworking

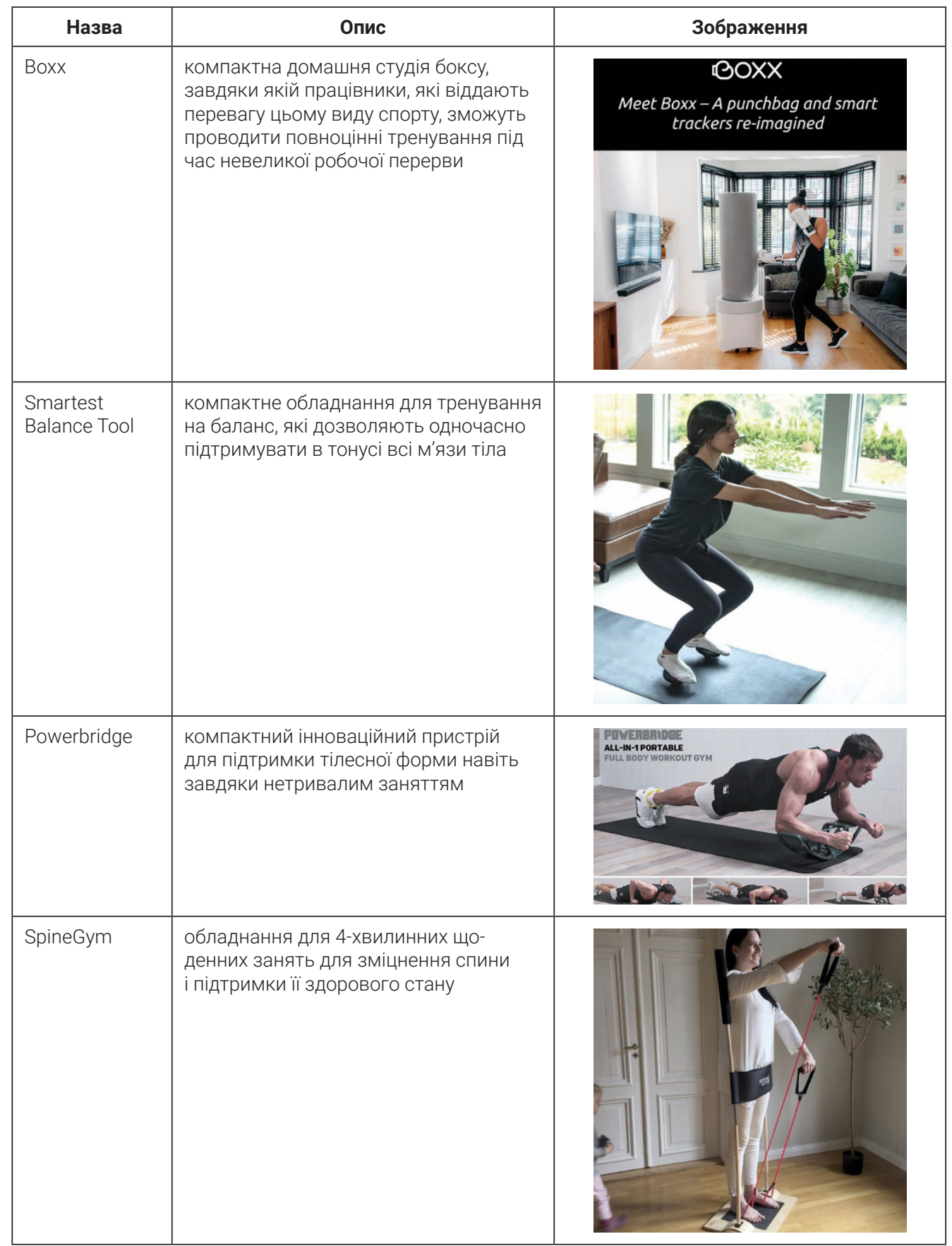


Деміург: ідеї, технології, перспективи дизайну 2021 Том 4 № 2 Demiurge: ideas, technologies, perspectives of design 2021 Vol. 4 No 2

Продовження табл. 1

\begin{tabular}{|l|l|l|}
\hline Speediance & $\begin{array}{l}\text { обладнання для занять силовими тре- } \\
\text { нуваннями всього тіла за допомогою } \\
\text { персонального тренажерного залу на } \\
\text { основі штучного інтелекту }\end{array}$ \\
\hline
\end{tabular}

Серед нових типів оздоблювальних матеріалів можна виділити такі сучасні матеріали оформлення інтер'єру: «квітучі» шпалери зі спеціальною термофарбою, яка змінює свій колір і декор залежно від зміни температури; спеціальні композити, здатні пропускати світло і змінювати забарвлення; рідкі-шпалери; смарт-скло.

Отже, аналіз джерел показав насиченість ринку інноваційними технологіями, існує великий вибір рішень у залежності від мети використання, зонування, розмірів і гаманця. У розробленій класифікації зібрано найефективніші приклади інтелектуальних систем, що можуть використовуватися резидентами офісу, а також їхній ефективний вплив на фізичне і ментальне здоров'я.

\section{Наукова новизна та практична значимість дослідження}

Наукова новизна одержаних результатів полягає в узагальненні й систематизації основних прийомів та особливостей формування гнучкого простору коворкінгів. Вперше виявлено та систематизовано застосування інтелектуальних систем та інноваційних технологій до функціональних зон основного і другорядного значення. Розроблено практичні рекомендації використання інноваційних технологій в архітектурно-дизайнерському проєктуванні коворкінгів.

Основні теоретичні положення, прикладні результати і висновки дослідження можуть бути використані у подальших наукових дослідженнях, при коригуванні наявних і створенні нових нормативних положень стосовно архітектурно-дизайнерської діяльності, проєктуванні офісних приміщень загалом і коворкінгів, зокрема. Сформовані рекомендації щодо формування архітектурно-дизайнерських рішень коворкінгів з використанням інноваційних технологій сприятимуть розвитку громадських просторів, підвищенню рівня якості надання послуг у них, зміцненню загального відчуття задоволеності від використання даного сервісу клієнтами. 
Висновки 6 У результаті проведеного аналізу зарубіжних і вітчизняних аналогів коворкінг-просторів було виявлено основні закономірності їхнього формування. Оскільки основним завданням коворкінгу є поєднання вільного графіку і дисципліни, то проєктна діяльність формування дизайну коворкінгу спрямована на створення цілісного гармонійного предметно-технічного простору середовища життєдіяльності людини.

У результаті проведеного дослідження виділено 3 групи користувачів коворкінгу: власники, працівники і резиденти. Відповідно до цих груп обґрунтовано вимоги до офісного простору. Спираючись на отриманий сет вимог і маючи на увазі інші зовнішні чинники, що впливають на організацію робочого простору, у проведеному дослідженні класифіковано зони коворкінгу за функціональним призначенням. Це дозволило більш конкретно оцінити можливості використання інтелектуальних систем та інноваційних технологій у кожній окремій зоні та розробити рекомендації щодо їх використання. У результаті дослідження було систематизовано ефективність використання офісних меблів та аксесуарів (регульованих стільниць, стійок під ноутбук ергономічних крісел, подушок тощо) для комбінування форматів роботи протягом дня. Обґрунтовано доцільність застосування автономних настільних міні-садів у робочих зонах, димерних розумних систем освітлення всього простору, а також інших інтелектуальних систем для зміни робочого настрою на атмосферу відпочинку і спокою. Також виявлена ефективність використання компактних, часто портативних, тренажерів для фізичних навантажень у спортивних кімнатах у просторі коворкінгу. Установка таких інтелектуальних систем та інноваційних технологій стає яскравим індикатором прояву піклування про фізичне й ментальне здоров'я резидентів.

Говорячи про коворкінги, ми розуміємо, що як і будь-який бізнес, явище орієнтоване на отримання максимуму вигоди за мінімуму витрат. Але, зважаючи на обсяги пропозиції на ринку коворкінг-просторів, ці середовища не можуть собі дозволити не звертати увагу на внутрішній дизайн і обмежитись створенням звичайного невиразного простору. А зважаючи на те, що компанії з іменем і вболіванням за свою репутацію зорієнтовані на фізіологічний і психологічний стан своїх працівників, то дизайн офісів, у тому числі й коворкінгів, має відповідати останнім тенденціям із застосуванням інноваційних технологій та розумних систем. 


\section{Список бібліографічних посилань}

Маркова, И. В. (2015). Инновационные технологии в дизайне тканей для интерьера. Традиції та новації у вищій архітектурно-художній освіті, 1, 118-123.

Олешко, О., \& Петровська, Ю. (2018). Використання елементів фітодизайну при формуванні інтер'єрів центрів коворкінгу. Архітектурний вісник КНУБА, 14-15, 143-152.

Олійник, О. П., Гнатюк, Л. Р., \& Чернявський, В. Г. (2011). Основи дизайну інтер'єру. Національний авіаційний університет.

Приходько, К. (2020). Специфіка інтер'єру середовища сучасних коворкінг-центрів. Вісник КНУКіМ. Серія: Мистецтвознавство, 43, 197-203.

Радченко, Ю. С., \& Шмельова, О. Є. (2018, 26-27 квітня). Особливості формування дизайну інтер'єру коворкінг-центрів на базі ВНЗ. В Наукові розробки молоді на сучасному етапі, тези доповідей XVII Всеукраїнської наукової конференції молодих вчених та студентів (Т. 1, с. 442-443). Київський національний університет технологій та дизайну.

Фельдблюм, В. Ш. (2013). «Нано» на стыке наук: нанообъекты, нанотехнологии, нанобудущее. https://narfu.ru/university/library/books/0706.pdf

Шмельова, О. Є., Сафронова, О. О., Булгакова, Т. В., \& Синицька, М. О. (2019). Особливості дизайну просторів сучасних коворкінгів залежно від їх функціонального призначення. Art and Design, 4, 119-131. https://doi.org/10.30857/2617-0272.2019.4.11

Di Risio, A. (2020, March 7). Global Coworking Growth Study 2020. Coworker.com. https://www. coworkingresources.org/blog/key-figures-coworking-growth

\section{References}

Di Risio, A. (2020, March 7). Global Coworking Growth Study 2020. Coworker.com. https://www. coworkingresources.org/blog/key-figures-coworking-growth [in English].

Feldblium, V. Sh. (2013). "Nano" na styke nauk: nanoob"ekty, nanotekhnologii, nanobudushchee ["Nano" at the Junction of Sciences: Nanoobjects, Nanotechnology, Nanofuture]. https:// narfu.ru/university/library/books/0706.pdf [in Russian].

Markova, I. V. (2015). Innovatsionnye tekhnologii v dizaine tkanei dlya inter'era [Innovative Technologies in Textile Design for Interios]. Traditions and Novations of the Higher Architectonic and Art Education, 1, 118-123 [in Russian].

Oleshko, O., \& Petrovska, Yu. (2018). Vykorystannia elementiv fitodyzainu pry formuvanni inter'ieriv tsentriv kovorkinhu [The Use of Phytodisign Elements in Formationof Coworking Centers' Interiors]. Arkhitekturnyi visnyk KNUBA, 14-15, 143-152 [in Ukrainian].

Oliinyk, O. P., Hnatiuk, L. R., \& Cherniavskyi, V. H. (2011). Osnovy dyzainu inter'ieru [Basics of Interior Design]. National Aviation University [in Ukrainian].

Prykhodko, K. (2020). Spetsyfika inter'ieru seredovyshcha suchasnykh kovorkinh-tsentriv [Interior Design Key Features for Modern Coworking Centre Environment]. Bulletin of KNUKiM. Series in Arts, 43, 197-203 [in Ukrainian].

Radchenko, Yu. C., \& Shmelova, O. Ye. (2018, April 26-27). Osoblyvosti formuvannia dyzainu inter'ieru kovorkinh-tsentriv na bazi VNZ [Features of Interior Design of Coworking Centers on the Basis of Universities]. In Naukovi rozrobky molodi na suchasnomu etapi [Scientific Developments of Youth at the Present Stage], Abstracts of the XVII All-Ukrainian Scientific Conference of Young Scientists and Students (Vol. 1, pp. 442-443). Kyiv National University of Technology and Design [in Ukrainian].

Shmelova, O. Ye., Safronova, O. O., Bulhakova, T. V., \& Synytska, M. O. (2019). Osoblyvosti dyzainu prostoriv suchasnykh kovorkinhiv zalezhno vid yikh funktsionalnoho pryznachennia [Peculiarities of Design of Modern Coworking Spaces Depending on their Functional Purpose]. Art and Design, 4, 119-131. https://doi.org/10.30857/2617-0272.2019.4.11 [in Ukrainian]. 